\title{
Ny praksismodell gjorde studentene bedre i ledelse og organisering
}

Ved UiT får førsteårsstudentene veiledning på sykehjem av sisteårsstudentene for å styrke handlingskompetansen i sykepleiefaglig ledelse.

\section{Forfattere}

\section{Wivi-Ann Tingvoll}

Dosent

Institutt for helse- og omsorgsfag, Universitet i Troms $\varnothing$ - Norges arktiske universitet, Narvik

\section{Karin Ravn Pedersen}

Universitetslektor

Institutt for helse- og omsorgsfag, Universitet i Troms $\emptyset$ - Norges arktiske universitet, Narvik

\section{Randi Inger Johanne Nymo}

Førsteamanuensis

Institutt for helse- og omsorgsfag, Universitetet i Troms $\varnothing$ - Norges arktiske universitet, Narvik

\section{Nøkkelord}

\section{Fokusgrupper Hermeneutikk Kommunehelsetjenesten Kunnskapsbasert sykepleie}

Sykepleiefaglig ledelse

Sykepleien Forskning 2018 13(73575)(e-73575)

DOI: https://doi.org/10.4220/Sykepleienf.2018.73575 
Bakgrunn: Sykepleiere er den største gruppen helsepersonell i den kommunale helse- og omsorgstjenesten. Det forventes at de allerede som nyutdannede har kompetanse i sykepleiefaglig ledelse for å kunne organisere og lede pasientarbeidet. Sykepleierutdanningen i samarbeid med praksisfeltet har ansvaret for å utvikle teoretisk og praktisk kunnskap slik at sykepleiere får handlingskompetanse i sykepleiefaglig ledelse.

Hensikt: Hensikten med denne studien var å få kunnskap om hvordan studentene erfarer sin egen utvikling av handlingskompetanse i sykepleiefaglig ledelse etter ny praksismodell i sjette semester. Studentenes erfaringer gir viktig kunnskap for å videreutvikle praksismodellen i henhold til praksisfeltets krav til nyutdannede sykepleiere.

Metode: Vi valgte en kvalitativ tilnærming ved å bruke fokusgrupper med studenter etter endt praksisperiode våren 2016. I analysen benyttet vi kvalitativ innholdsanalyse.

Resultat: Studien viser at en ny praksismodell kan bidra til å styrke studentenes ferdigheter i ledelse og organisering og dermed bidra til å minske gapet mellom utdanningen og sykehjemmenes forventninger til nyutdannede sykepleiere.

Konklusjon: Studentene ble utfordret i sykepleiefaglig ledelse, studentveiledning, involvering i kvalitetsarbeid samt tverrprofesjonell samhandling. Studien viser at balansen mellom utfordringer og refleksjon er sentral for læring og kritisk tenkning i sykepleie.

Endringene i helse- og omsorgssektoren de senere

årene har ført til krav om bedre samhandling, koordinering og mer effektive tjenester samtidig som pasientsikkerheten og kvaliteten skal ivaretas (1-3). Disse endringene har betydning for utdanningen av helsepersonell, og utdanningen må samsvare med behovet for kompetanse - spesielt i kommunehelsetjenesten (4).

\section{Sykepleiefaglig ledelse}

Tidligere forskning viser at mer oppmerksomhet på kompetanse i sykepleiefaglig ledelse bidrar til å sikre en god kvalitet på omsorg og pasientbehandling $(5,6)$. 
Sykepleiefaglig ledelse innebærer oppgaver som skal sikre faglig innhold og flyt i arbeidsprosesser relatert til pasientarbeid $(7,8)$. Hovedoppgaven er å vurdere pasientenes behov for sykepleie, vurdere sykepleietiltak og koordinere samhandling med andre profesjoner. I denne funksjonen ligger også ansvaret for å delegere oppgaver, følge opp og samarbeide med medarbeidere samt samhandle tverrprofesjonelt.

Sykepleiere har i tillegg ansvaret for faglig oppdatering og dokumentasjon (8).

Sykepleiefaglig ledelse er krevende og kjennetegnes av at arbeidsmetodene har tydelige mål, at faglige problemer løses i fellesskap med andre, og at ferdigheter i kommunikasjon og samhandling er avgjørende (9). I læringsutbyttebeskrivelsene etter endt sykepleierutdanning er det krav til kunnskaper og ferdigheter i koordinering, fagutvikling og formidling, og det forventes at kandidaten er en endringsdyktig leder i sitt eget fag (10).

\section{Tidligere forskning}

Tidligere studier viser imidlertid at nyutdannede sykepleiere mangler kompetanse i sykepleiefaglig ledelse, og at de ikke er forberedt på oppgaver knyttet til ledelse og organisering av pasientarbeidet (11-14). Forskning viser også at nyutdannede sykepleiere ikke har fått handlingskompetanse i sykepleiefaglig ledelse før tre år etter endt utdanning $(11,13)$.

\section{«Tidligere studier viser at nyutdannede sykepleiere mangler kompetanse i sykepleiefaglig ledelse.»}

Samtidig har arbeidsgivere en forventning om at

sykepleiere har denne kompetansen på ansettelsestidspunktet. Flere påpeker at for å møte gapet mellom utdanningen og arbeidsgiverens forventninger er det behov for å styrke sykepleierutdanningen, spesielt i ledelse og organisering $(5,9,12,15)$. 


\section{Begrepsavklaring}

I rammeplanen for sykepleierutdanningen benyttes

begrepene «handlingsberedskap» og «handlingskompetanse» (16). Handlingsberedskap innebærer områder der utdanningen bidrar til at nyutdannede sykepleiere har kunnskap om feltet, men mangler erfaring til å kunne handle selvstendig (16).

Handlingskompetanse innebærer områder der utdanningen har ansvaret for at nyutdannede sykepleiere skal kunne fungere på selvstendig grunnlag. Kompetansen er knyttet både til den fagspesifikke konteksten, den enkeltes mentale prosess og den sosiale konteksten der kompetansen utvikles og anvendes (17). Handlingskompetansen utvikles og realiseres gjennom handling.

\section{Studentenes handlingskompetanse}

Ved Universitetet i Troms $ø$ - Norges arktiske universitet (UiT), studiested Narvik, ønsket vi å styrke sykepleierstudentenes handlingskompetanse i sykepleiefaglig ledelse. Vi utarbeidet emneplan i sjette semester for en ny praksismodell på sykehjem (18). Emneplanen fokuserer på at studentene skal ha fått handlingskompetanse i å lede og organisere sykepleie, delta i tverrprofesjonelt samarbeid samt veilede førsteårsstudenter, medarbeidere og pasienter.

Studentene gjennomfører et arbeidskrav i løpet av praksisperioden. Arbeidskravet fokuserer på helsefremmende og forebyggende sykepleie, noe som innebærer prosjektledelse og samhandling med flere aktører. Videre skal studentene ha kunnskap om og bidra til kvalitetsforbedrende tiltak, internkontroll og avviksrapportering.

Vi utarbeidet praksismodellen i samarbeid med ledere og praksisveiledere på sykehjem. Samarbeidet med praksisfeltet var nødvendig for å få en felles forståelse av det faglige innholdet i emnet og hvilke forpliktelser utdanningen og praksisfeltet har for å gjennomføre praksismodellen. 


\section{Hensikten med studien}

Hensikten med studien vår var å få kunnskap om hvordan studentene erfarer egen utvikling av handlingskompetanse i sykepleiefaglig ledelse etter ny praksismodell i sjette semester. Studentenes erfaringer gir viktig kunnskap for å videreutvikle praksismodellen i henhold til praksisfeltets krav til nyutdannede sykepleiere.

Forskningsspørsmålet i denne studien er som følger:

Hvordan erfarer studentene at de kan utvikle handlingskompetanse i sykepleiefaglig ledelse når de har praksis på sykehjem?

\section{Metode}

For å få svar på forskningsspørsmålet brukte vi en kvalitativ tilnærming med et deskriptivt og utforskende design. Vi benyttet fokusgruppeintervju som datainnsamlingsmetode. Diskusjonen mellom deltakerne bidro til ideer om eventuelle forbedringer og kunne gi flere nyanser av temaet.

Det er to viktige elementer som inngår ved bruk av fokusgruppeintervju. Det første er at gruppen må ledes av en moderator som skal presentere et klart tema og hjelpe til med å holde deltakerne til temaet uten å påvirke gruppen. Det andre er fokusgruppeintervjuets mål om å bringe frem deltakernes oppfatninger om samt holdninger og følelser til temaet som blir presentert (19). Metoden egner seg derfor godt til å samle inn data for å utvikle praksis (20).

\section{Fokusgruppeintervjuer}

Vi gjennomførte fokusgruppeintervjuene i studien etter endt praksisperiode våren 2016. Utvalget var studenter som hadde avviklet praksis på fire ulike sykehjem. Vi foretok tre fokusgruppeintervjuer ledet av en moderator. En av forfatterne gjennomførte to fokusgruppeintervjuer, mens den andre ledet ett. Den tredje forfatteren transkriberte datamaterialet. 
Antall deltakere i fokusgruppeintervjuene varierte fra to til sju, og totalt tolv studenter var med i studien. Vi hadde utarbeidet en temaguide med seks åpne spørsmål som dreide seg om hvordan studentene erfarte å lede og administrere avdelingen, hvordan de erfarte å være veiledere for førsteårsstudenter, og hvordan praksisen bidro til kunnskap om sykepleiefaglig ledelse.

Deltakerne var aktive, og moderatorens rolle ble å sørge for at de diskuterte det oppgitte temaet.

Moderatoren hadde god kunnskap om innholdet $\mathrm{i}$ praksismodellen og kunne følge opp viktige elementer innenfor temaene. Fokusgruppeintervjuene ble tatt opp digitalt og transkribert ordrett.

\section{Metodekritikk}

Moderatoren var lærerveileder for studentene da de gjennomførte praksisen, noe som kunne ha betydning for hva studentene valgte å bringe inn $\mathrm{i}$ fokusgruppeintervjuene. Studentene hadde avsluttet praksisen, slik at diskusjonene ikke påvirket sluttvurderingen.

Vi delte ut informasjonsskriv og forespørsel om å delta i prosjektet til et strategisk utvalg av totalt tjue studenter som hadde gjennomført praksis på fire sykehjem i sjette semester. Frafallet av åtte studenter kan ha sammenheng med at intervjuene ble foretatt etter avsluttet praksisperiode, og at studentene var i gang med andre oppgaver. På grunn av frafallet kort tid før intervjuene besto to grupper av kun to og tre deltakere pluss moderatoren.

Det at to av gruppene hadde få deltakere, førte til at interaksjonen mellom deltakerne ikke var optimal, og diskusjonene ble mindre nyanserte. Samtidig som få deltakere kan hindre grupperinger i fokusgruppeintervjuer, kan det være vanskelig å få frem tilsvarende nyanser som fremkommer i en større gruppe (19). 
Til tross for få fremmøtte valgte vi likevel å gjennomføre fokusgruppeintervjuene av hensyn til deltakerne. På bakgrunn av ressurssituasjonen gjennomførte vi fokusgruppeintervjuene uten observatør, noe som kan ha ført til mindre oppmerksomhet på interaksjonen i gruppene.

Vi har vært delaktige i hele prosessen fra å veilede studentene i praksis til å gjennomføre fokusgruppeintervjuene, tolke og analysere det som kom frem. Den av oss som ikke hadde en moderatorrolle i fokusgruppeintervjuene, fikk et «utenforperspektiv» på materialet.

\section{Etiske overveielser}

Vi innhentet skriftlig, informert samtykke, og deltakerne ble informert om at de når som helst kunne trekke seg fra undersøkelsen, noe ingen gjorde. Studien ble meldt inn til Norsk senter for forskningsdata (NSD). Vi anonymiserte personidentifiserbare opplysninger i transkriberingen og lagret dataene etter gjeldende retningslinjer ved UiT.

\section{Analyse}

Vi benyttet kvalitativ innholdsanalyse inspirert av Graneheim, Lindgren og Lundman (21, 22). Kvalitativ innholdsanalyse kjennetegnes ved en systematisk analyse av teksten, der man ønsker å forstå hvordan teksten gir mening og innhold til et bestemt fenomen (22).

I den første delen av analysen leste vi gjennom all tekst flere ganger for å få en oversikt over datamaterialet. Deretter delte vi teksten inn i meningsenheter, som ble kondensert og kodet. For å få frem det manifeste innholdet i materialet analyserte vi frem underkategorier. Dermed kom det frem fire kategorier:

- Erfaring i sykepleiefaglig ledelse Veiledningserfaring 
- Deltakelse i kvalitetsarbeid

- Utfordring med manglende tverrprofesjonell samhandling

Tabell 1. Eksempel på analyseprosessen

\begin{tabular}{lllll}
\hline Meningsenheter & Kondensering & Koder & Underkategori & Kategori \\
$\begin{array}{l}\text { «Jeg tror det er viktig at man som student } \\
\text { får litt erfaring med lederrollen. Vi er } \\
\text { bedre rustet etter en slik praksis.» }\end{array}$ & $\begin{array}{l}\text { Erfaringer med leder- } \\
\text { rollen gjør at jeg er } \\
\text { bedre forberedt. }\end{array}$ & $\begin{array}{l}\text { Bedre forberedt } \\
\text { i lederrollen }\end{array}$ & $\begin{array}{l}\text { Erfaring utvikler } \\
\text { sykepleiefaglig } \\
\text { ledelse }\end{array}$ & $\begin{array}{l}\text { Erfaring i } \\
\text { sykepleiefaglig } \\
\text { ledelse }\end{array}$ \\
$\begin{array}{l}\text { «Dette med å veilede studenter synes } \\
\text { jeg var veldig bra. Vi er i siste fase av } \\
\text { studieforløpet og føler oss tryggere på å } \\
\text { veilede andre. Det er greit å få litt erfaring, } \\
\text { og så vet vi hva vi kan gjøre bedre.» }\end{array}$ & $\begin{array}{l}\text { Siste fase i student- } \\
\text { forløpet gir trygghet } \\
\text { til å veilede andre } \\
\text { studenter. }\end{array}$ & $\begin{array}{l}\text { Trygghet i } \\
\text { veiledning }\end{array}$ & $\begin{array}{l}\text { Kompetanse } \\
\text { gjennom utdan- }\end{array}$ & $\begin{array}{l}\text { Veilednings- } \\
\text { erfaring }\end{array}$ \\
\hline
\end{tabular}

\section{Resultat}

Her presenterer vi funnene fra studien inndelt i de fire ovennevnte kategoriene, underbygd av utsagn fra deltakerne i fokusgruppeintervjuene.

\section{Erfaring i sykepleiefaglig ledelse}

Våre funn viser at studentene var tilfredse med at de ble utfordret til å skulle fungere som sykepleiefaglige ledere på avdelingen. De fikk erfare at praksisveiledere «sto bak» og overlot mye av ansvaret for den daglige organiseringen av pasientarbeidet til studentene. Det gjorde at studentene følte seg trygge på utfordringene de fikk.

\section{三 «Studentene var tilfredse med at de ble utfordret til å skulle fungere som sykepleiefaglige ledere på avdelingen.»}

En deltaker sa følgende: «Vi er blitt utfordret og har fått kjenne på hvilket ansvar vi har når vi er ferdige sykepleiere.» En annen uttrykte dette: «Jeg tror det er viktig at man som student får litt erfaring med lederrollen. Vi er bedre rustet etter en slik praksis.» 
Mange av studentene opplevde en større tillit for faglig ståsted i personalgruppen. Studentene diskuterte det faktumet at deres synspunkter og faglige innspill ble anerkjent og hørt på en annen måte enn i tidligere praksisperioder. En deltaker sa det slik: «Jeg opplevde fra dag én i denne praksisen at vi ble hørt. Innspill i forhold til pasientene ble tatt i betraktning. De var mer åpne for å høre på oss siden vi snart er ferdige sykepleiere.»

I løpet av praksisperioden skulle studentene overta arbeidet i to dager. Personalet kunne avvikle møter og internopplæring, mens studentene hadde ansvaret for pasientene og førsteårsstudentene. Deltakerne beskrev dette arbeidet som god erfaring, som også utfordret dem til å organisere sitt eget arbeid. En deltaker sa følgende: «Det var veldig lærerikt å lede avdelingen, og jeg ble utfordret til å delegere arbeidsoppgaver ... det er litt vanskelig.»

\section{Veiledningserfaring}

Sykepleierstudenter har veiledning av førsteårsstudenter som et av arbeidskravene i praksisperioden i sjette semester. Funnene tyder på at alle deltakerne hadde stort utbytte av denne oppgaven. De snakket om at deres egen erfaring med ulike praksisveiledere ga større innsikt i rollen som veileder.

En av deltakerne sa det slik: «Dette med å veilede studenter synes jeg var veldig bra. Vi er i siste fase av studieforløpet og føler oss tryggere på å veilede andre. Det er greit å få litt erfaring, og så vet vi hva vi kan gjøre bedre.» En annen uttalte som følger: «Mange tar lett på det å være veileder. Det krever faktisk en del jobb, både før og etter. Hva kunne vi gjort annerledes ... for å komme med tilbakemeldinger.»

Studentene skulle ha ansvaret for avdelingens drift i to dager sammen med førsteårsstudentene. Som veiledere måtte de være bevisste på at stell kan ta tid, og førsteårsstudentene måtte veiledes til å bruke pasientenes ressurser. 
En deltaker sa som følger: «De [førsteårsstudentene] var for sene med å jobbe fordi de manglet erfaring. Jeg hadde en [student] som brukte en og en halv time til dusj der pasienten klarte det meste selv. De er for forsiktige i begynnelsen.»

\section{Deltakelse i kvalitetsarbeid}

Studentene diskuterte erfaringene sine med avviksrapporteringen fra praksisperioden. De hadde mange konkrete eksempler på situasjoner der avvik ble registrert og dokumentert. Våre funn tyder på at det er ulik praksis ved de ulike institusjonene, og at det var uklart for studentene hva de skulle skrive avvik på.

En sa det slik: «Terskelen for å skrive avvik var veldig stor. Det skulle ganske mye til før det ble skrevet avvik.» Det var tydelig at flere av studentene ikke fikk klarhet i hvilke rutiner som gjaldt eller hvordan avviksmeldinger håndteres videre i systemet, noe som denne deltakeren uttrykte på denne måten: «Vi spurte om hvor det ble av disse avviksmeldingene, hva som gjøres med dem, og hvem det er som ser dem. Jeg ble ikke klok på det, altså.»

Som sykepleiefaglige ledere på avdelingene fikk studentene erfaring med å dokumentere sykepleie. Deltakerne var entydige på at dokumentasjonen var manglende, og at rapportene for det meste var muntlige rapporter om pasientenes situasjon. En deltaker sa det på denne måten: «Dokumentasjonen er en utfordring på avdelingen, ikke noe felles holdning til det.»

\section{三 «Som sykepleiefaglige ledere på avdelingene fikk studentene erfaring med å dokumentere sykepleie.»}


Deltakerne var kritiske til at det kun var sykepleierne som dokumenterte og veldig få av de andre ansatte eller få av vikarene. En deltaker uttalte følgende: «Det skrives veldig kort og masse unyttig. Så når jeg leste dokumentasjonen, lurte jeg på hva som var vitsen med å skrive dette. Jeg hadde ikke godtatt det hvis jeg skulle jobbet der.»

\section{Utfordring med manglende tverrprofesjonell samhandling}

Studien tyder på at de ansatte på sykehjemmene hadde lite tverrprofesjonell samhandling. De ulike tjenestene, som for eksempel fysioterapi og ergoterapi, rekvireres til den enkelte pasienten ved behov.

Sykepleierne samhandlet i hovedsak med legen, og mye av kontakten med andre yrkesgrupper foregikk via telefon. Deltakerne følte at de hadde et godt samarbeid med legen, og at de var blitt utfordret med tanke på å svare på spørsmål og diskutere behandling og medisinering.

Noen studenter derimot snakket om utfordringer i dialogen med legen. En deltaker uttalte som følger: «I starten måtte jeg på en måte føye meg etter det legen sa. Jeg fikk tips av sykepleierne om hva jeg burde si, så det gikk bedre etter hvert.» En annen sa dette: «Mange ganger måtte man stå på sitt for å få ting gjennom når det gjaldt pasienten. Vi kjenner pasienten best.»

\section{Diskusjon}

Studien viser at studentene fikk større innsikt i sykepleierens lederrolle på sykehjem etter den nye praksismodellen. Sykepleiefaglig ledelse må styrkes fordi sykehjemmene er preget av få sykepleierstillinger, underbemanning og økt press på sykepleierne (23, 24). Det betyr et stort individuelt ansvar og krav til faglig kyndighet hos den enkelte sykepleieren (7). 
Den sykepleiefaglige lederrollen ble tydeliggjort ved at studentene deltok både i pasientnære og organisatoriske gjøremål. En praksis som har hovedtyngden på sykepleiefaglig ledelse, kan bidra til å utfordre både utdanningen og praksisfeltet $\mathrm{i}$ kunnskapsbasert praksis. Studentene blir oppdatert på ny teori og blir bevisste på sykepleiernes kjerneverdier som er nødvendige for å utvikle handlingskompetanse (25).

Praksisveilederens tilnærming styrket studentenes engasjement og ga rom for å stille kritiske spørsmål. Kritisk refleksjon og dialog kan øke den faglige kvaliteten på sykehjem som læringsarena (9).

\section{Bedre handlingskompetanse}

De innsamlede dataene viser at når studentene overtok avdelingen over en gitt periode, førte det til at de «løftet blikket» og så både kliniske og organisatoriske utfordringer med å være sykepleiefaglig leder.

Studentene måtte organisere pasientarbeidet til flere pasienter og fordele arbeidsoppgaver til medarbeidere, noe som utfordret dem på teamarbeid. Oppmerksomhet på individuell omsorg og sykepleiernes kjerneverdier ble ivaretatt (25).

Studentenes handlingskompetanse økte ved at den stedlige ledelsen, praksisveilederen og lærerveilederen ga dem tillit og ansvar som de var i stand til å mestre. Praksisveilederne var tilgjengelige og sørget for at studentene ivaretok den faglige forsvarligheten. Ifølge Blekken og medarbeidere (12) gir avdelingsovertakelse studentene mer realistisk erfaring som sykepleiefaglige ledere.

\section{Veilederstudentene opplevde mestring}


Et tema i emnebeskrivelsen er kommunikasjon og veiledning, som er en av forutsetningene for å skape tillit og god samhandling med pasienter, pårørende, kollegaer og studenter. Orvik (9) omtaler veiledning av medarbeidere som en viktig del av faglig ledelse.

Studentene ble utfordret til å veilede førsteårsstudenter i grunnleggende sykepleie.

Funnene viser at studentene opplevde at de mestret veiledningen av studentene i første studieår, noe som støttes av andre studier (12). Deltakernes handlingskompetanse i veiledning ble utviklet ved at de hadde tilstrekkelig tid og aktivt måtte bruke sin teoretiske kompetanse og erfaring i veiledning.

\section{Utviklet bevissthet om kvalitetsarbeid}

Funnene viser at det i varierende grad var lagt til rette for å gjennomføre krav til kvalitetsutvikling i sykehjem. Dette kan blant annet henge sammen med sykepleiernes begrensede tid, ressurser og kunnskap om oppfølging av krav som stilles til sykehjem (23). Arntzen (26) hevder at de sterkeste virkemidlene i kvalitetsarbeidet er fagpersonalets kunnskap og kompetanse samt gleden over å lykkes med jobben.

\section{三 «Studentene utviklet gradvis en bevissthet om kvalitetsarbeid og var kritiske til den manglende oppfølgingen.»}

Funnene viser at studentene fikk utviklet sin handlingskompetanse ved å delta aktivt i avviksregistrering samtidig som de uttrykte usikkerhet med tanke på hvordan avvik ble håndtert videre i organisasjonen. Avvikshåndtering er muligens ikke ansett som viktig kunnskap hos sykepleiere i kommunehelsetjenesten (12). 
Studien viser at studentene gradvis utviklet en bevissthet om kvalitetsarbeid og var kritiske til den manglende oppfølgingen. Det gjaldt spesielt rapportering og håndtering av avvik og dokumentasjon av sykepleie. Studentene så også nødvendigheten av å faglig begrunne rutineendringer. Sykepleierne som veiledet studentene i denne praksisperioden, erfarte at studentene ble viktige diskusjonspartnere og kom med konkrete forslag til forbedringer (27). Praksismodellen kan på den måten bidra til kvalitetsforbedring av praksis.

\section{Tverrfaglig samarbeid}

Funnene viser at studentene hadde liten erfaring med tverrprofesjonell tilnærming til pasienter i sykehjem. En forutsetning for å få et helhetlig tilbud til pasientene er tett samhandling mellom sykepleiere og andre faggrupper ut fra pasientenes individuelle behov (1). Mangel på ulike fagprofesjoner i kommunehelsetjenesten fører til reduserte tilbud på sykehjem.

Når studentene har få erfaringer med tverrprofesjonelt samarbeid, kan det føre til at de ikke blir bevisste på sykepleiernes rolle i et tverrprofesjonelt samarbeid. Sykepleiefaglig ledelse handler om å sikre samarbeid og flyt i pasientarbeidet (9). Bevissthet på egen rolle og ansvar som faglig leder krever mer oppmerksomhet på tverrprofesjonell tilnærming for å ivareta kompleksiteten i pasientbehandling på sykehjem (28).

Sykepleierens lederrolle innebærer å bygge relasjoner og utvikle grupper til team (9). Når det er mangel på andre profesjoner på sykehjem, stiller det større krav til sykepleiernes kompetanse. 
Som ferdigutdannede sykepleiere skal studentene langt på vei være i stand til å møte utfordringene som kreves av fremtidens helse- og omsorgstjeneste. Den nye emneplanen skal styrke studentene i sykepleiefaglig ledelse ved at søkelyset ikke bare er satt på handlingsberedskap, men også på handlingskompetanse. Kompetanse i sykepleiefaglig ledelse vil bli sentralt for sykepleiere i den kommunale helse- og omsorgstjenesten også i fremtiden (29, 30).

\section{Konklusjon}

Hensikten med studien vår var å få kunnskap om studentenes erfaringer med hvordan ny praksismodell kan bidra til å styrke sykepleiefaglig ledelse etter ny praksismodell i sjette semester. Studien viser at en ny praksismodell kan bidra til å styrke studentenes ferdigheter i ledelse og organisering, og dermed bidra til å minske gapet mellom utdanningen og sykehjemmenes forventninger til nyutdannede sykepleiere.

Studentene deltok aktivt i sykepleiernes oppgaver og funksjoner på sykehjemmet sammen med praksisveilederne og det øvrige personellet. Studien viser at et kritisk blikk på blant annet kvalitet på sykepleien og manglende tverrprofesjonelt samarbeid bidrar til diskusjoner og øker sykepleiernes bevissthet om sitt faglige ansvar.

Praksismodellen skal utvikles videre i samarbeid med studenter, praksisveiledere og lærerveiledere. Vi holder på med videre studier av praksisveilederes og enhetslederes erfaringer med å ha implementert ny praksismodell. Det vil også være interessant med en oppfølgingsstudie av studenter som er utdannet etter den nye praksismodellen.

\section{Referanser}


1. St.meld. nr. 47 (2008-2009).

Samhandlingsreformen - Rett behandling - på rett sted - til rett tid. Oslo: Helse og omsorgsdepartementet; 2009.

2. Lov 24. juni $2011 \mathrm{nr} .30$ om kommunale helseog omsorgstjenester m.m. (helse- og omsorgstjenesteloven). Tilgjengelig fra: https://lovdat a.no/dokument/NL/lov/2011-06-24-30 (nedlastet 03.06.2018).

3. Meld. St. nr. 11 (2014-2015). Kvalitet og pasientsikkerhet. Oslo: Helse- og omsorgsdepartementet; 2014.

4. Meld. St. nr. 13 (2011-2012). Utdanning for velferd. Oslo: Kunnskapsdepartementet; 2012.

5. Curtis EA, de Vries J, Sheerin FK. Developing leadership in nursing: exploring core factors. British Journal of Nursing. 2011;20(5):306-9.

6. Dyess S, Sherman R. Developing the leadership skills of new graduates to influence practice environments: a novice nurse leadership program. Nursing Administration Quarterly. 2011;35(4):313-22.

7. Kristoffersen NJ. Sykepleierens ansvar og arbeidsområder i helsetjenesten. I: Kristoffersen NJ, Nortvedt F, Skaug E-A, Grimsbø GH, red. Grunnleggende sykepleie. Sykepleie - fag og funksjon, bind 1. Oslo: Gyldendal Akademisk; 2016.

8. Pfeiffer R. Sykepleier og leder : den administrative og den faglige sykepleielederens funksjon. Bergen: Fagbokforlaget; 2002.

9. Orvik A. Organisatorisk kompetanse : innføring i profesjonskunnskap og klinisk ledelse. Oslo: Cappelen Damm Akademisk; 2015. 
10. Universitetet i Tromsø, Norges arktiske universitet. Fagplan Bachelor i sykepleie 2016. Tilgjengelig fra: https://uit.no/Content/479258/cache= 20171003123257/Fagplan-bachelor-i-sykepleie-h\%C 3\%B8st2016.pdf (nedlastet 01.03.2018).

11. Solli H. Nyutdannede sykepleieres utvikling fra handlingsberedskap til handlingskompetanse.

Sykepleien Forskning. 2009;4(1):52-60. Tilgjengelig fra: https://sykepleien.no/forskning/2009/04/nyutdanne de-sykepleieres-utvikling-fra-handlingsberedskap-til-h andlingskompetanse (nedlastet 01.11.2018).

12. Blekken LE, Medby AO, Forbord T. Læringsutbytte i sykepleiefaglig ledelse etter praksis der sykepleierstudenter overtok ansvaret for en avdeling. Sykepleien Forskning. 2013;8(4):344-52. Tilgjengelig fra: https://sykepleien.no/forskning/2013/ 11/laeringsutbytte-i-sykepleiefaglig-ledelse-etter-praks is-der-sykepleierstudenter (nedlastet 18.10.2018).

13. Dyess S, Sherman RO. Developing a leadership mindset in new graduates. Nurse Leader. 2010;8(1):29-33.

14. Ekström L, Idvall E. Being a team leader: newly registered nurses relate their experiences. Journal of nursing management. 2015;23(1):75-86.

15. Nilsen SR, Gjellebæk C, Brynhildsen S, Tjøstolvsen I, Johansen SG. Studenter trenger å lære organisering. Sykepleien 2015;103(11):60-3. Tilgjengelig fra: https://sykepleien.no/forskning/2015/

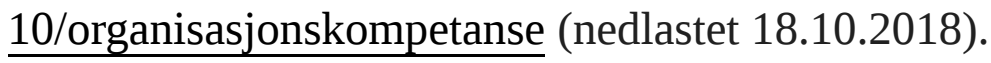

16. Kunnskapsdepartementet. Rammeplan for sykepleierutdanningen 2008. Tilgjengelig fra: https://w ww.regjeringen.no/globalassets/upload/kd/vedlegg/uh/ rammeplaner/helse/rammeplan_sykepleierutdanning_0 8.pdf (nedlastet 03.06.2018). 
17. Nygren P. Handlingskompetanse : om

profesjonelle personer. Oslo: Gyldendal Akademisk;

2004.

18. Universitetet i Tromsø, Norges arktiske universitet. Læreplan for praksisstudier kommunehelsetjenesten 6. semester. Narvik; 2017. (Upublisert).

19. Halkier B. Fokusgrupper. Oslo: Gyldendal Akademisk; 2010.

20. Karlsson B, Lerdal A. Bruk av fokusgruppeintervju. Sykepleien Forskning. 2008;3(3):172-5. Tilgjengelig fra: https://sykepleien.n o/forskning/2009/02/bruk-av-fokusgruppeintervju (nedlastet 01.11.2018).

21. Graneheim UH, Lindgren BM, Lundman B. Methodological challenges in qualitative content analysis: A discussion paper. Nurse Education Today. 2017;56:29-34.

22. Graneheim UH, Lundman B. Qualitative content analysis in nursing research: concepts, procedures and measures to achieve trustworthiness. Nurse Education Today. 2004;24(2):105-12.

23. Gautun H, Øien H, Bratt C. Underbemanning er selvforsterkende. Konsekvenser av mangel på sykepleiere i hjemmesykepleien og sykehjem. Rapport 6/16: Oslo: NOVA, Velferdsforskningsinstituttet; 2016.

24. Pedersen KR, Tingvoll W-A.

Kompetanseutfordringer i sykehjem - en studie basert på sykepleieres erfaring fra hverdagssituasjoner. I:

Kassah BL, Tingvoll W-A, Kassah AK, red. Samhandlingsreformen under lupen : kvalitet, organisering og makt i helse- og omsorgstjenestene. Bergen: Fagbokforlaget; 2014. 
25. Karoliussen M. Tilbake til kjerneverdiene.

Sykepleien. 2015;103(2):62-4. Tilgjengelig fra: http

s://sykepleien.no/forskning/2015/02/tilbake-til-kjernev

erdiene (nedlastet 18.10.2018).

26. Arntzen E. Ledelse og kvalitet i helsetjenesten : arbeidsglede og orden i eget hus. Oslo: Gyldendal Akademisk; 2014.

27. Pedersen K, Nymo R, Tingvoll W-A. De kommer som sykepleiere, ikke som studenter. Geriatrisk sykepleie. 2018;(1):28-35. Tilgjengelig fra: https://sykepleien.no/meninger/innspill/2018/02/de-ko mmer-som-sykepleiere-ikke-som-studenter (nedlastet 18.10.218).

28. Tingvoll W-A, Sæterstrand TM. Sykehjemmets rolle i fremtidens helsevesen. Tidsskrift for Den norske legeforening. 2007;127(17):2274-5.

29. Meld. St. nr. 26 (2014-2015). Fremtidens primærhelsetjeneste - nærhet og helhet. Oslo: Helse og omsorgsdepartementet; 2015.

30. Tyrholm BV, Kvangarsnes M, Bergem R. Mellomlederes vurdering av kompetansebehov i sykepleie etter samhandlingsreformen. I: Kvangarsnes M, Håvold JI, Helgesen H, red. Innovasjon og entreprenørskap. Oslo: Universitetsforlaget; 2016. 